\title{
PENGARUH BUDAYA ORGANISASI DAN LINGKUNGAN KERJA TERHADAP KINERJA KARYAWAN CV. REVARI PUTRA PRATAMA PALEMBANG
}

\author{
Sugeng Mianto Fane, SE. M.Si \\ Dosen Fakultas Ekonomi Universitas Palembang
}

\begin{abstract}
ABSTRAK
Permasalahan dalam penelitian ini adalah " apakah budaya organisasi dan lingkungan kerja berpengaruh secara parsial dan simultan terhadap kinerja?" Pengujian hipotesis menggunakan analisis regresi linear berganda, melalui uji $\mathrm{T}$ dan uji $\mathrm{F}$, dengan maksud untuk mengetahui pengaruh variabel independen terhadap variabel dependent pada tingkat kepercayaan $95 \%(\mathrm{a}=0,05)$.

Hasil penguji pada uji $\mathrm{T}$ pada variabel budaya organisasi berpengaruh positif terhadap kinerja, hal terlihat dari nilai $\mathrm{t}_{\text {hitung }}(3,480)>\mathrm{t}_{\text {tabel }}(2.368)$, signifikansi $(0,00)$ di bawah atau lebih kecil dari 0, 05, sedangkan pada variabel lingkungan kerja berpengaruh positif terhadap kinerja, hal terlihat dari nilai $t_{\text {hitung }}(2,926)>t_{\text {tabel }}(2,368)$ dan signifikansi $(0,00)$ di bawah atau lebih kecil dari 0,05 . Pada pengujian pada uji $F$ pada variabel budaya organisasi dan lingkungan kerja berpengaruh positif terhadap kinerja, hal terlihat dari nilai $\mathrm{F}$ hitung $(4,326)>F_{\text {tabel }}(3,340)$, dan signifikansi $(0,01)$ di bawah atau lebih kecil dari 0,05 .
\end{abstract}

Kata Kunci : Budaya Organisasi, Lingkungan Kerja \& Kinerja

\section{LATAR BELAKANG}

Sumber daya manusia bagi sebuah perusahaan adalah salah satu bagian terpenting. Karyawan merupakan salah satu sumber daya manusia yang merupakan bagian penggerak dari perusahaan yang mempunyai potensi untuk berkembang. Karyawan secara aktif mendorong produktifitas dalam memenuhi tujuan sebuah perusahaan. Hubungan sinergis antara perusahaan dan karyawan sangat diperlukan untuk mencapai tujuan perusahaan bersama. Perlu adanya suatu manajemen sumber daya manusia untuk mengelola karyawan sebuah perusahaan.

Hasibuan (2015:12) menyatakan bahwa manusia selalu berperan aktif dalam menentukan rencana, sistem, proses, tujuan yang ingin dicapai oleh perusahaan. Tujuan tidak mungkin terwujud tanpa peran karyawan meskipun dukungan sarana dan prasarana serta sumber dana yang dimiliki perusahaan tidak akan ada manfaatnya bagi perusahaan, jika peran aktif karyawan tidak diikutsertakan. Hal ini menunjukkan bahwa sumber daya manusia merupakan kunci pokok yang harus diperhatikan dengan segala kebutuhannya. Pengelolaan sumber daya terkait dan mempengaruhi kinerja organisasional dengan cara menciptakan nilai atau menggunakan keahlian sumber daya manusia yang berkaitan dengan praktek manajemen dan sasarannya cukup luas. Oleh karena itu faktor manusia juga perlu mendapatkan perhatiaan dari pimpinan atau manajer sehingga pegawai dapat bekerja dengan lebih baik dan tujuan dari organisasi dapat tercapai.

Dalam organisasi atau perusahaan tentunya mempunyai kepribadian, dan kepribadian tersebut merupakan sebuah organisasi. Menurut Robbins dan Judge (2012:76) menyatakan bahwa budaya organisasi mengacu pada sebuah sistem makna bersama yang dianut oleh para anggota yang membedakan organisasi 
tersebut dengan organisasi lainya. Budaya organisasi merupakan salah satu unsur dalam pemberdayaan karyawan dalm perusahaan. Organisasi yang memiliki budaya yang kuat dapat mempunyai pengaruh yang bermakna bagi perilaku dan sikap anggotanya (Robbins, 2012:79). Budaya organisasi dapat mempengaruhi karyawan dalam bertingkah laku, cara bekerja dengan tim dan cara menggambarkan pekerjaan. Tanpa adanya budaya organisasi, seorang karyawan cenderung merasa segan untuk melaksanakan suatu tugas dengan baik apapun statusnya dalam organisasi tersebut, karena kurang jelasnya kesepakatan komitmen (Sulaksono, 2013:43). Sehingga kinerja karyawan yang tinggi sangat dipengaruhi faktor budaya organisasi. Konsep budaya organisasi merupakan salah satu alat untuk meningkatkan kinerja karyawan, karena budaya organisasi mempengaruhi pola pikir, perasaan dan cara karyawan bertindak dalam perusahaan.

Melalui perencanaan sumber daya manusia yang baik, produktivitas kerja dari setiap individu dapat ditingkatkan, hal tersebut dapat diwujudkan melalaui adanya penyesuaian dan dari kebiasaan-kebiasaan organisasi dan individu. Perkembangan dunia usaha saat ini semakin bertambah pesat, sehingga perusahaan diharapkan mampu mengunakan sumber daya manusia dengan sebaik-baiknya. Pengelolaan sumber daya manusia di maksudkan agar suatu perusahaan mampu untuk menyatukan persepsi atau cara pandang karyawan dan pimpinan dalam rangka mencapai tujuan organisasi antara lain dengan memberikan motivasi kerja, bimbingan, pengarahan dan koordinasi yang baik dalam bekerja oleh seorang pemimpin pada bawahannya. Hal ini perlu dibenahi demi pencapaian yang diinginkan oleh perusahaan. Penguatan kinerja karyawan adalah salah satu yang harus dilakukan. Beberapa faktor yang diprediksi dapat meningkatkan kinerja karyawan diantaranya adalah budaya organisasi dan lingkungan kerja. Konsep budaya organisasi merupakan salah satu alat untuk meningkatkan kinerja karyawan, karena budaya organisasi mempengaruhi pola pikir, perasaan dan cara karyawan bertindak dalam perusahaan.

Berkaitan dengan objek penelitian CV. Revari Putra Pratama Palembang, peneliti mengadakan pra survei dimana masih ada karyawan yang mempunyai budaya organisasi yang kurang baik. Hal terlihat ketidakhadiran karyawan dalam bekerja dan keluar masuk karyawan (turnover). Berikut ini data ketidakhadiran karyawan CV. Revari Putra Pratama Palembang dari tahun 2020-2021

Tabel 1

Rekapitulasi Absensi Karyawan

CV. Revari Putra Pratama Palembang

Tahun 2020

\begin{tabular}{|c|c|c|c|c|c|c|c|c|c|}
\hline \multirow[b]{2}{*}{$\begin{array}{l}\text { Bulan } \\
\text { Januari }\end{array}$} & \multirow{2}{*}{$\begin{array}{c}\text { Total } \\
\text { Karyawan }\end{array}$} & \multirow{2}{*}{$\begin{array}{l}\text { Total } \\
\text { Hari } \\
\text { Kerja }\end{array}$} & \multirow{2}{*}{\begin{tabular}{|c} 
Total \\
Kehadiran \\
Karyawan \\
Seharusnya
\end{tabular}} & \multicolumn{4}{|c|}{ Absensi Karyawan } & \multirow[b]{2}{*}{$\begin{array}{c}\text { Total } \\
\text { Kehadiran }\end{array}$} & \multirow{2}{*}{$\begin{array}{l}\text { Persentase } \\
\text { Ketidak } \\
\text { hadiran } \\
\text { Karyawan }\end{array}$} \\
\hline & & & & Sakit & Izin & $\begin{array}{c}\text { Tanpa } \\
\text { Ket. }\end{array}$ & Total & & \\
\hline Januari & 42 & 26 & 1092 & 10 & 8 & 2 & 20 & 1072 & 1,87 \\
\hline Februari & 40 & 23 & 920 & 12 & 7 & 4 & 23 & 897 & 2,56 \\
\hline Maret & 40 & 26 & 1040 & 15 & 6 & 3 & 26 & 1014 & 2,56 \\
\hline April & 43 & 24 & 1032 & 8 & 8 & 4 & 20 & 1012 & 1,98 \\
\hline
\end{tabular}




\begin{tabular}{|c|c|c|c|c|c|c|c|c|c|}
\hline Mei & 45 & 24 & 1080 & 12 & 10 & 3 & 25 & 1055 & 2,37 \\
\hline Juni & 45 & 18 & 810 & 9 & 7 & 2 & 20 & 790 & 2,53 \\
\hline Juli & 44 & 26 & 1144 & 14 & 10 & 3 & 27 & 1117 & 2,42 \\
\hline Agustus & 42 & 25 & 1050 & 12 & 12 & 2 & 26 & 1024 & 2,54 \\
\hline September & 44 & 25 & 1100 & 14 & 9 & - & 22 & 1078 & 2,04 \\
\hline Oktober & 40 & 27 & 1080 & 12 & 10 & 3 & 25 & 1055 & 2,37 \\
\hline November & 40 & 25 & 1000 & 10 & 9 & 4 & 23 & 977 & 2,35 \\
\hline Desember & 39 & 24 & 936 & 9 & 7 & 4 & 20 & 916 & 2,18 \\
\hline \multicolumn{8}{|c|}{} \\
\hline
\end{tabular}

Sumber : CV. Revari Putra Pratama Palembang (2020)

Tabel 2

Rekapitulasi Absensi Karyawan

CV. Revari Putra Pratama Palembang

Tahun 2021

\begin{tabular}{|c|c|c|c|c|c|c|c|c|c|}
\hline \multirow[b]{2}{*}{$\begin{array}{l}\text { Bulan } \\
\text { Januari }\end{array}$} & \multirow{2}{*}{$\begin{array}{c}\text { Total } \\
\text { Karyawan }\end{array}$} & \multirow{2}{*}{$\begin{array}{c}\text { Total } \\
\text { Hari } \\
\text { Kerja }\end{array}$} & \multirow{2}{*}{\begin{tabular}{|c} 
Total \\
Kehadiran \\
Karyawan \\
Seharusnya
\end{tabular}} & \multicolumn{4}{|c|}{ Absensi Karyawan } & \multirow[b]{2}{*}{$\begin{array}{c}\text { Total } \\
\text { Kehadiran }\end{array}$} & \multirow{2}{*}{$\begin{array}{c}\text { Persentase } \\
\text { Ketidak } \\
\text { hadiran } \\
\text { Karyawan }\end{array}$} \\
\hline & & & & Sakit & Izin & $\begin{array}{c}\text { Tanpa } \\
\text { Ket. }\end{array}$ & Total & & \\
\hline Januari & 39 & 26 & 1014 & 12 & 9 & 4 & 25 & 989 & 2,53 \\
\hline Februari & 39 & 23 & 987 & 13 & 8 & 6 & 27 & 960 & 2,81 \\
\hline Maret & 36 & 25 & 900 & 16 & 6 & 5 & 27 & 873 & 3,20 \\
\hline April & 36 & 23 & 828 & 18 & 8 & 4 & 30 & 798 & 3,76 \\
\hline Mei & 35 & 24 & 840 & 20 & 6 & 4 & 30 & 810 & 3,70 \\
\hline Juni & 35 & 22 & 770 & 12 & 8 & 2 & 22 & 748 & 2,94 \\
\hline Juli & 33 & 26 & 858 & 15 & 6 & 8 & 29 & 829 & 3,50 \\
\hline Agustus & 33 & 26 & 858 & 18 & 4 & 2 & 24 & 834 & 2,88 \\
\hline September & 32 & 25 & 875 & 14 & 6 & 3 & 23 & 852 & 2,70 \\
\hline Oktober & 31 & 26 & 806 & 13 & 7 & 2 & 22 & 784 & 2,81 \\
\hline November & 31 & 25 & 775 & 14 & 4 & 2 & 20 & 755 & 2,65 \\
\hline Desember & 31 & 25 & 775 & 15 & 7 & 1 & 23 & 752 & 3,06 \\
\hline \multicolumn{9}{|c|}{ Persentase Rata-Rata } & 3,05 \\
\hline
\end{tabular}

Sumber : CV. Revari Putra Pratama Palembang (2021)

Tabel diatas terlihat

rata-rata persentase ketidakhadiran karyawan CV. Revari Putra Pratama Palembang pada tahun 2020 sebesar $2,10 \%$, Pada tahun 2021 sebesar 3,05\%. Melihat persentase ketidakhadiran karyawan CV. Revari Putra Pratama
Palembang cenderung mengalami kenaikan.

Menurut Mudiarta (2013:97) rata-rata persentasi jumlah ketidakhadiran karyawan yang normal adalah sebesar 3\% per tahun. Sedangkan yang terjadi di CV. Revari Putra Pratama Palembang 
ketidakhadiran karyawan dibawah 3\%, hal ini berarti persentase rata-rata tingkat ketidakhadiran karyawan CV. Revari Putra Pratama Palembang cenderung normal karena masih dibawah $3 \%$, akan tetapi perusahaan menghendaki agar tingkat ketidakhadiran karyawan sebesar $1 \%$.

Mengukur tingkat loyalitas karyawan selain dengan melihat daftar absensi karyawan dapat juga dengan melihat tingkat pergantian karyawan (turnover), di mana tingkat pergantian karyawan menunjukkan jumlah karyawan yang masuk dan yang keluar di CV. Revari Putra Pratama Palembang selama lima tahun. Data pergantian karyawan (turnover) pada dapat dilihat pada tabel sebagai berikut :

Tabel 3

Turnover Karywan

CV. Revari Putra Pratama Palembang

Tahun 2020

\begin{tabular}{|l|l|c|c|c|}
\hline No & \multicolumn{1}{|c|}{ Bulan } & Masuk & Keluar & Total karyawan \\
\hline 1 & Januari & 2 & - & 42 \\
\hline 2 & Februari & - & 2 & 40 \\
\hline 3 & Maret & - & - & 40 \\
\hline 4 & April & & 3 & 43 \\
\hline 5 & Mei & - & - & 45 \\
\hline 6 & Juni & 3 & - & 45 \\
\hline 7 & Juli & - & 1 & 44 \\
\hline 8 & Agustus & - & - & 42 \\
\hline 9 & September & - & - & 44 \\
\hline 10 & Oktober & - & 2 & 40 \\
\hline 11 & November & 2 & 1 & 40 \\
\hline 12 & Desember & - & - & 39 \\
\hline & Total & 7 & 9 & \\
\hline
\end{tabular}

Sumber : CV. Revari Putra Pratama Palembang (2020)

Dari tabel diatas merupakan data turnover karyawan pada CV. Revari Putra Pratama Palembang diamana pada tahun 2020 adanya karyawan masuk sebanyak 7 orang di antaranya: pada bulan Januari sebanyak 2 orang karyawan, pada bulan Juni sebanyak 3 orang karyawan, pada bulan November sebanyak 1 orang karyawan, lalu untuk karyawan keluar ada sebanyak 9 orang di antaranya, pada bulan Februari ada sebanyak 2 orang karyawan keluar, bulan April ada sebanyak 3 orang karyawan keluar, bulan Juli ada sebanyak1 orang karyawan keluar, bulan Oktober ada sebanyak 2 orang karyawan keluar, bulan November ada sebanyak 1 orang karyawan keluar. 
Tabel 4

Turnover Karywan CV. Revari Putra Pratama Palembang

Tahun 2021

\begin{tabular}{|c|l|c|c|c|}
\hline No & \multicolumn{1}{|c|}{ Bulan } & Masuk & Keluar & Total karyawan \\
\hline 1 & Januari & - & - & 39 \\
\hline 2 & Februari & - & - & 39 \\
\hline 3 & Maret & - & 3 & 36 \\
\hline 4 & April & - & - & 36 \\
\hline 5 & Mei & - & 1 & 35 \\
\hline 6 & Juni & - & - & 35 \\
\hline 7 & Juli & - & 2 & 33 \\
\hline 8 & Agustus & - & - & 33 \\
\hline 9 & September & - & 1 & 32 \\
\hline 10 & Oktober & - & 1 & 31 \\
\hline 11 & November & - & - & 31 \\
\hline 12 & Desember & - & - & 31 \\
\hline
\end{tabular}

Sumber : CV. Revari Putra Pratama Palembang (2021)

Dari tabel diatas merupakan data turnover karyawan pada CV. Revari Putra Pratama Palembang dimana pada tahun 2021 adanya karyawan yang keluar sebanyak 8 orang yaitu pada bulan Maret sebanyak 3 orang, bulan Mei 1 orang, bulan Juli 2 orang, bulan September 1 orang dan bulan Oktober 1 orang karyawan.

Faktor yang mempengaruhi kinerja selain budaya organisasi adalah lingkungan kerja. Lingkungan kerja merupakan aspek yang harus diperhatikan pihak perusahaan karena akan menumbuhkan semangat kerja karyawan. Secara umum lingkungan kerja adalah tempat dimana karyawan melaksanakan tugas baik yang berupa fisik maupun non fisik. Lingkungan kerja fisik adalah faktor yang berpengaruh untuk meningkatkan kinerja karyawan. Faktor-faktor lingkungan kerja fisik yang baik dan nyaman bagi pegawai dapat menjamin karyawan bekerja dengan bersemangat sehingga berpengaruh terhadap kinerja karyawan maka diperlukan perhatian khusus mengenai lingkungan kerja. Untuk meningkatkan aktivitas perusahaan, maka perusahaan harus memperhatikan faktor lingkungan kerja fisiknya seperti udara, suara, cahaya, dan warna. lingkungan kerja adalah, tempat bekerja, fasilitas yang mendukung dalam bekerja serta hubungan kerja dalam perusahaan itu sendiri 
Tabel 5

\section{Keadaan Lingkungan Kerja Fisik \\ CV. Revari Putra Pratama Palembang}

\begin{tabular}{|c|c|l|}
\hline \multicolumn{2}{|c|}{ K e a d a a n } \\
\hline Penerangan & $:$ & Kurang terang, karena bola lampu yang sudah usang dan harus diganti \\
\hline Suhu Udara & $:$ & $\begin{array}{l}\text { Terasa agak panas, karena pendingin ruangan dalam hal ini Air } \\
\text { Conditioner (AC) tidak mampu bekerja dengan maksimal karena AC } \\
\text { tersebut jarang sekali di service }\end{array}$ \\
\hline Pewarnaan & $:$ & Warna cat susah pudar karena sudah 3 tahun tidak ada pengecatan ulang \\
\hline Layout & $: \begin{array}{l}\text { Selain itu tata letak peralatan kantor yang tidak tertata dengan baik, } \\
\text { dimana peralatan (tamping rammer, plate compactor, mesin press, } \\
\text { mesin miter potong, mesin cut off, mesin las trafo, mesin kompresor, } \\
\text { mesin router dan peralatan lainya) berserakan dan tidak tersusun dengan } \\
\text { rapi. }\end{array}$ \\
\hline Penghijauaan & $:$ & $\begin{array}{l}\text { Tidak ada pohon untuk penghijauan atau pot-pot bunga-bunga, sehingga } \\
\text { terlihat gersang. }\end{array}$ \\
\hline
\end{tabular}

Sumber: CV. Revari Putra Pratama Palembang (2021)

CV. Revari Putra Pratama Palembang adalah perusahaan swasta yang bergerak dibidang general kontraktor, maintenance dan supplier. Adapun budaya kerja yang diterapkan oleh CV. Revari Putra Pratama Palembang ternyata belum dapat meningkatkan antusianisme karyawan untuk bekerja. Kenyataan tersebut dilihat dari adanya peningkatan jumlah karyawan yang terlambat masuk kerja serta meningkatnya absensi karyawan serta keadaan lingkungan kerja yang kurang memadai sehingga karyawan merasa jenuh dengan keadaan sekelilingnya, sehingga menurunkan kinerja karyawan $\mathrm{CV}$. Revari Putra Pratama Palembang.

Berdasarkan hasil prasurvei dengan memberikan kuesioner kepada 15 orang karyawan sebagai sampel awal dan informasi yang diperoleh dari pimpinan $\mathrm{CV}$. Revari Putra Pratama Palembang yaitu Bapak Zulman Marzuki. diketahui bahwa selama ini penurunan kinerja karyawan disebabkan oleh beberapa faktor yang tersaji pada tabel di bawah ini:

Tabel 6

Hasil Survei Mengenai Penyebab Menurunnya Kinerja Karyawan CV. Revari Putra Pratama Palembang

\begin{tabular}{|c|l|c|c|}
\hline No & \multicolumn{1}{|c|}{$\begin{array}{c}\text { Faktor Penyebab Menurun } \\
\text { Kinerja Karyawan }\end{array}$} & $\begin{array}{c}\text { Jumlah } \\
\text { Jawaban }\end{array}$ & Persentase \\
\hline 1 & Kualitas hasil pekerjaan & 3 & $20 \%$ \\
\hline 2 & Ketidak tepatan penyelesaian pekerjaan & 3 & $20 \%$ \\
\hline 3 & Tingkat kehadiran yang menurun & 3 & $20 \%$ \\
\hline 4 & Kurangnya kerjasama antar karyawan & 4 & $26,67 \%$ \\
\hline 5 & Kurangnya rasa tanggung jawab & 2 & $13,33 \%$ \\
\hline & Total & 15 & $100 \%$ \\
\hline & prasurvein \\
\hline
\end{tabular}

Sumber: Hasil prasurvei CV. Revari Putra Pratama Palembang (2021) 
Hasil survey tersebut menunjukkan sebanyak 3 orang (20\%) menurunnya kinerja karyawan disebabkan ketidaktepatan penyelesain tugas, sebanyak 3 orang (20\%) mengatakan bahwa menurunnya kinerja karena tingkat kehadiran yang menurun sehingga banyak pekerjaan yang terbengkalai, sebanyak 3 orang $(20 \%)$, sebanyak karyawan karena hasil kualitas pekerjaan tidak sesuai dengan apa yang rencanakan, sebanyak 4 orang (26,67\%) mengatakan bahwa menurunnya kinerja karyawan karena karyawan CV. Revari Putra Pratama Palembang kurang bekerjasama dengan karyawan lain dalam menyelesaikan pekerjaan atau suatu tugas yang ditentukan oleh perusahaan dan sebanyak 2 orang $(13,33 \%)$ mengatakan bahwa menurunnya kinerja karyawan karena kurangnya rasa tangung jawab dalam menyelesaikan tugasnya.

Berdasarkan fenomena inilah yang terjadi di CV. Revari Putra Pratama Palembang sehingga tertarik untuk melakukan penelitian dengan judul " Pengaruh Budaya Organisasi dan Lingkungan Kerja Terhadap Kinerja Karyawan CV. Revari Putra Pratama Palembang".

\subsection{Perumusan Masalah}

Berdasarkan uraian latar belakang di atas, maka penulis merumuskan permasalahan dalam penelitian ini adalah sebagai berikut:

1. Apakah budaya organisasi $\left(X_{1}\right)$ dan lingkungan kerja $\left(\mathrm{X}_{2}\right)$ berpengaruh secara parsial terhadap kinerja (Y) karyawan CV. Revari Putra Pratama Palembang?

2. Apakah budaya organisasi $\left(X_{1}\right)$ dan lingkungan kerja $\left(\mathrm{X}_{2}\right)$ berpengaruh secara simultan terhadap kinerja $(\mathrm{Y})$ karyawan CV. Revari Putra Pratama Palembang?

\section{I. TINJAUAN PUSTAKA}

A. Budaya Organisasi

\section{Pengertian Budaya Organisasi}

Budaya organisasi adalah nilai-nilai dan norma yang dianut dan dijalankan oleh sebuah organisasi terkait dengan lingkungan dimana organisasi tersebut menjalakan kegiatannya (Erni 2015, 56). Sedangkan menurut Kreitner Budaya organisasi adalah satu wujud anggapan yang dimiliki, yang diterima secara implicit oleh kelompok dan menentukan bagaimana kelompok tersebut rasakan, pikirkan, dan bereaksi terhadap lingkungannya yang beraneka ragam (Kreitner Robert 2015: 79).

Menurut Deninson (2014:82) budaya organisasi adalah nilai-nilai, keyakinan dan prinsip-prinsip dasar yang merupkan landasan bagi system dan praktek-praktek manajemen serta perilaku yang meningkatkan dan menguatkan prinsip-prinsip tersebut. Menurut Nawawi (2016:207), budaya organisasi adalah suatu sistem nilai dan keyakinan bersama yang diambil dari pola kebiasaan dan falsafah dasar pendiriannya yang kemudian berinteraksi menjadi norma-norma, dimana norma tersebut dipakai sebagai pedoman cara berpikir dan bertindak dalam upaya mencapai tujuan bersama. Sedangkan menurut pendapat Ashar Sunyoto Munandar (2016:262) budaya organisasi terdiri dari asumsi-asumsi dasar yang dipelajari baik sebagai hasil memecahkan masalah yang timbul dalam proses penyesuaian dengan lingkungannya, maupun sebagai hasil memecahkan masalah yang timbul dari dalam organisasi.

\section{Fungsi Budaya Organisasi}

Menurut Pabundu Tika (2016:14) dalam bukunya yang berjudul "Budaya Organisasi dan Peningkatan Kinerja Perusahaan", menyatakan bahwa terdapat 10 fungsi utama budava organisasi, 
diantaranya :

1. Sebagai batas pembeda terhadap lingkungan, organisasi maupun

2. Sebagai perekat bagi anggota organisasi dalam suatu organisasi.

3. Mempromosikan stabilitas sistem sosial. Hal ini tergambarkan dimana

4.Sebagai mekanisme dalam memandu dan membentuk sikap serta perilaku anggota-anggota organisasi.

5. Sebagai integrator. Budaya organisasi dapat dijadikan integrator karena adanya sub-sub budaya baru.

6.Membentuk perilaku bagi anggota-anggota organisasi.

7. Sebagai saran untuk menyelesaikan masalah-masalah pokok organisasi.

8. Sebagai acuan dalam menyusun perencanaan pemasaran,

9. Sebagai alat komunikasi..

\section{Dimensi dan Indikator Budaya Organisasi}

Menurut Denison (2014:87) mengemukakan ada empat dimensi budaya organisasi yang terkait dengan tingkat efektivitas organisasi. Keempat dimensi tersebut adalah:

a Involvement

Merupakan dimensi budaya organisasi yang menunjukkan tingkat partisipasi karyawan (anggota organisasi) dalam proses pengambilan keputusan. Dimensi ini mempengaruhi efektivitas organisasi melalui mekanisme informal dan struktur formal organisasi.

b Consistency

Menunjukkan tingkat kesepakatan anggota organisasi terhadap asumsi dasar dan nilai-nilai inti organisasi. Dimensi ini mempengaruhi efektivitas melalui integrasi normatif yang direfleksikan dalam kecocokan antara ideology dengan praktik sehari-hari dan tingkat predictability system organisasi.

\section{c Adaptability}

Kemampuan organisasi dalam merespon perubahan - perubahan lingkungan eksternal dengan melakukan perubahan internal organisasi. Dimensi ini mempengaruhi efektivitas organisasi melalui tingkat fleksibilitas kondisi internal organisasi dan fokus organisasi terhadap aspek eksternal.

d Mission

Dimensi budaya yang menunjukkan tujuan inti organisasi yang menjadikan anggota organisasi teguh dan fokus terhadap apa yang dianggap penting oleh organisasi, dalam hal ini yang dimaksud dalam mission adalah komitmen atau keteguhan anggota organisasi terhadap suatu misi (Mission) yang merupakan pengejawantahan dari sebuah nilai-nilai yang dibangun oleh suatu perusahaan.

\section{B. Lingkungan Kerja \\ 1. Pengertian Lingkungan Kerja}

Lingkungan kerja merupakan salah satu faktor penting dalam menciptakan kinerja karyawan. Karena lingkungan kerja mempunyai pengaruh langsung terhadap karyawan didalam menyelesaikan pekerjaan yang pada akhirnya akan meningkatkan semangat kerja. Menurut Sedarmayanti (2015:110) lingkungan kerja merupakan keseluruhan alat perkakas dan bahan yang dihadapi, lingkungan sekitarnya dimana seseorang bekerja, metode kerjanya, serta pengaturan kerjanya baik sebagai perseorangan maupun sebagai kelompok. Dari pendapat tersebut dapat diterangkan bahwa terciptanya suasana kerja sangat dipengaruhi oleh struktur organisasi yang ada dalam organisasi tersebut.

Menurut Sedarmayanti (2016:102) 
menyatakan bahwa secara garis besar, jenis lingkungan kerja terbagi menjadi 2 yaitu:

1. Lingkungan Kerja Fisik

Lingkungan kerja fisik adalah semua keadaan berbentuk fisik yang terdapat di sekitar tempat kerja yang dapat mempengaruhi karyawan baik secara langsung maupun secara tidak langsung.
a. Pewarnaan
b. Penerangan
c. Udara
d. Suara bising
e. Ruang Gerak
f. Keamanan
g. Kebersihan

2. Lingkungan Kerja Non Fisik

Lingkungan kerja non fisik adalah semua keadaan yang terjadi yang berkaitan dengan hubungsn kerja, baik hubungan dengan atasan maupun hubungan dengan bawahan sesama rekan kerja, ataupun hubungan dengan bawahan

a.Struktur kerja,

b. Tanggung jawab kerja,

c . Perhatian dan dukungan pemimpin,

d . Kerja sama antar kelompok,

e. Kelancaran komunikasi,

\section{Kinerja}

\section{Pengertian Kinerja}

Guritno dan Waridin (2016:67)

kinerja merupakan perbandingan hasil kerja yang dicapai oleh karyawan dengan standar yang telah ditentukan. kinerja sebagai hasil kerja yang dicapai oleh individu yang disesuaikan dengan peran atau tugas individu tersebut dalam suatu perusahaan pada suatu periode waktu tertentu, yang dihubungkan dengan suatu ukuran nilai atau standar tertentu dari perusahaan dimana individu tersebut bekerja. Kinerja merupakan perbandingan hasil kerja yang dicapai oleh karyawan dengan standar yang telah ditentukan.

Dalam kerangka organisasi terdapat hubungan antara kinerja perorangan (individual performance) dengankinerja organisasi (organization performance). Suatu organisasi pemerintah maupun swasta besar maupun kecil dalam mencapai tujuan yang telah ditetapkan harus melalui kegiatan-kegiatan yang digerakkan oleh orang atau sekelompok orang yang aktif berperan sebagai pelaku, dengan kata lain tercapainya tujuan organisasi hanya dimungkinkan karena adanya upaya yang dilakukan oleh orang dalam organisasi tersebut.

\section{Indikator Variabel Kinerja Karyawan} Menurut Sentono (2014:97) indikator variabel kinerja sebagai berikut :

1) Jumlah pekerjaan ( $\left.Y_{1}\right)$

2) Kualitas pekerjaan ( $\left.Y_{2}\right)$

3) Pengetahuan atas tugas ( $\left.\mathrm{Y}_{3}\right)$

4) Kerja sama (Y4)

5) Tanggung jawab (Y5)

6) Sikap kerja (Y6)

7) Inisiatif (Y7)

8) Keterampilan teknis (Y8)

9) Kemampuan mengambil keputusan atau menyelesaikan masalah (Y9)

10) Kepemimpinan (Y10)

11) Administrasi (Y11)

12) Kreativitas (Y12) 


\section{Kerangka Fikir}

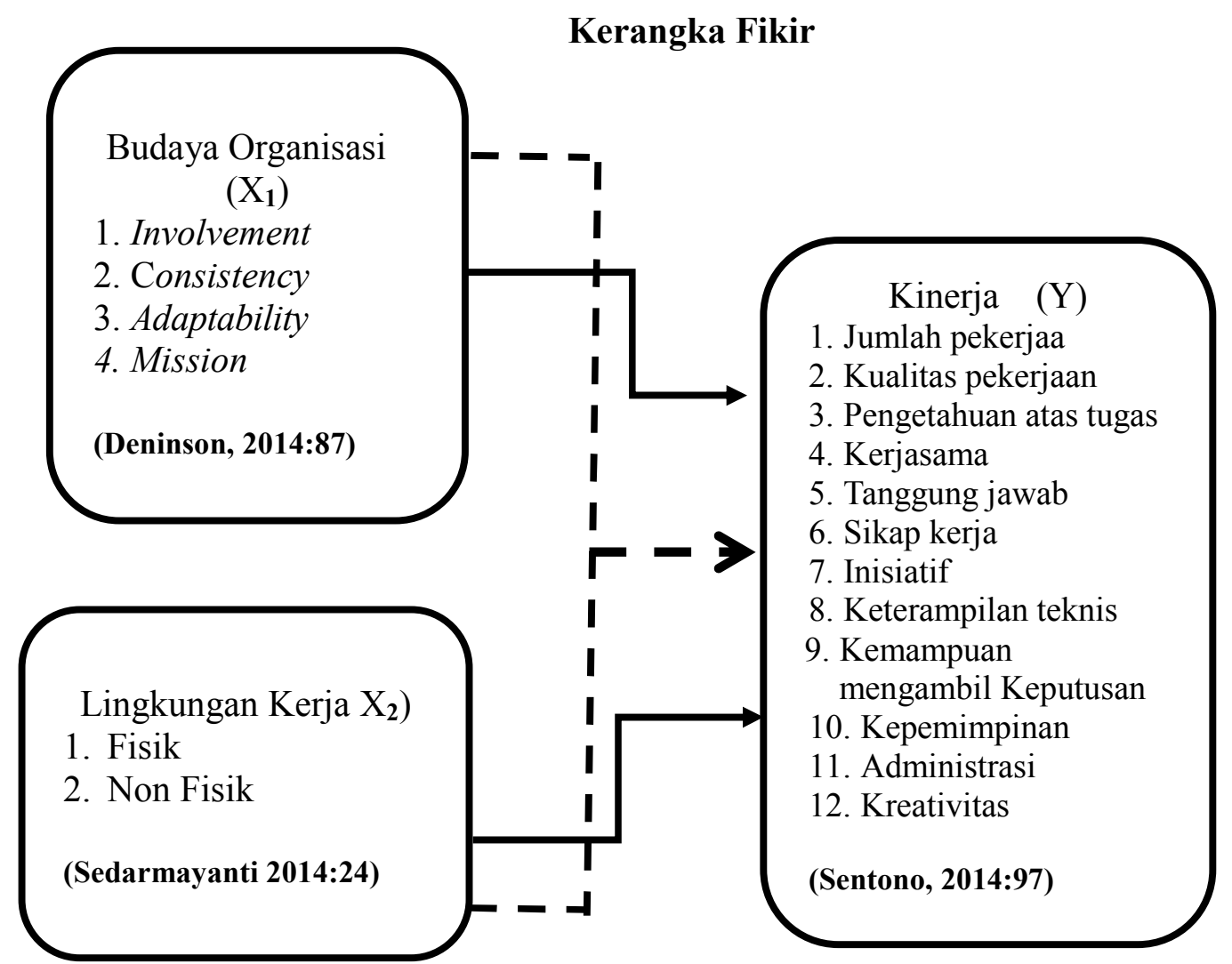

\section{Keterangan :}

......... : Simultan

\section{F. Hipotesis}

Hipotesis I

$\mathrm{H}_{0}$ : Tidak ada pengaruh budaya organisasi dan lingkungan kerja secara individu (parsial) terhadap kinerja karyawan CV. Revari Putra Pratama Palembang

$\mathrm{H}_{1}$ : Ada pengaruh budaya organisasi dan lingkungan kerja secara individu (parsial) terhadap kinerja karyawan CV. Revari Putra Pratama Palembang
Hipotesis 2

$\mathrm{H}_{0}$ : Tidak ada pengaruh budaya organisasi dan lingkungan kerja secara bersama-sama (simultan) terhadap kinerja karyawan CV. Revari Putra Pratama Palembang.

$\mathrm{H}_{1}$ : Ada pengaruh budaya organisasi dan lingkungan kerja secara bersama-sama (simultan) terhadap kinerja karyawan CV. Revari Putra Pratama Palembang 


\section{METODOLOGI PENELITIAN}

\subsection{Objek Penelitian}

Objek penelitian dilakukan di CV. Revari Putra Pratama Palembang yang beralamat di Jln. Pencak Silat Blok F No. 23 Palembang

\subsection{Ruang Lingkup Penelitian}

Agar penelitian ini tidak menyimpang dan terarah dari permasalah, maka peneliti membatasi masalah budaya organisasi dan lingkungan terhadap kinerja karyawan.

\subsection{Desain Penelitian}

Adapun penelitian ini adalah penelitiain Asosiatif penelitian yang berusaha mencari hubungan antara satu variabel dengan variabel lain. Dalam penelitian ini menggunakan hubungan kausal yaitu hubungan yang bersifat sebab-akibat dimana salah satu variabel (independen) mempengaruhi variabel yang lain (dependen). Adapun variabel yang diteliti dalam penelitian ini adalah variabel budaya organisasi $\left(\mathrm{X}_{1}\right)$, variabel lingkungan kerja $\left(\mathrm{X}_{2}\right)$, dan kinerja $\operatorname{karyawan}(Y)$.

\subsection{Teknik Analisis Data}

\section{a. Analisis Deskriptif Data}

Analisis deskriptif adalah cara merumuskan dan menafsirkan data yang ada sehingga memberikan gambaran yang jelas mengenai data yang akan diteliti yaitu :
a. Deskriptif responden
b. Deskriptif variabel penelitian

\section{b. Uji Instrumen Data}

\section{Uji Validitas dan Reliabilitas Data}

Validitas menunjukkan seberapa

nyata pengujian mengukur apa yang harusnya diukur (Situmorang et al, 2015:32). Uji validitas dilakukan untuk menguji data yang didapat apakah valid atau tidak dengan alat ukur yang digunakan yaitu dengan menggunakan responden sebagai sampel penelitian.. Pengujian validitas dilakukan dengan menggunakan program SPSS versi 24,00 dengan kriteria sebagai berikut:

a. Jika $\mathrm{r}$ hitung $>\mathrm{r}$ tabel, maka pertanyaan dinyatakan valid

b. Jika $\mathrm{r}$ hitung $<\mathrm{r}$ tabel, maka pertanyaan dinyatakan tidak valid Uji

\section{Reliabilitas}

Reliabilitas menunjukkan pada suatu pengertian bahwa instrumen cukup dapat dipercaya untuk dapat dipergunakan sebagai alat pengumpulan data karena instrumen sudah baik. Hasil suatu pengukuran dapat dipercaya apabila dalam beberapa kali pelaksanaan pengukuran terhadap subjek yang sama diperoleh hasil yang relatif sama, artinya mempunyai konsistensi pengukuran yang baik, dan suatu konstruk atau variabel dikatakan reliabel apabila memiliki Cronbach Alpha $>0,60$

\section{c. Analisis Desrkiptif Statistik 1. Koefesien Diterminasi}

Untuk mengetahui seberapa besar kemampuan variabel independen menjelaskan variabel dependen. Semakin besar nilai koefisien determinasi, maka semakin baik kemampuan variabel bebas menerangkan variabel terikat .Jika determinasi $\left(\mathrm{R}^{2}\right)$ semakin besar atau mendekati satu, maka dapat dikatakan bahwa variabel bebas semakin besar menjelaskan variabel terikat.

\section{Uji Regresi Berganda}

Analisis regresi linier berganda adalah pengaruh secara linear antara dua atau lebih variabel independen $\left(\mathrm{X}_{1}, \mathrm{X}_{2}, \ldots \mathrm{X}_{\mathrm{n}}\right)$ dengan variabel dependen (Y). Analisis ini untuk mengetahui arah pengaruh antara variabel independen dengan variabel dependen apakah masing-masing variabel independent berhubungan positif atau negatif dan untuk memprediksi nilai dari 
variabel dependen apabila nilai variabel independen mengalami kenaikan atau penurunan dengan persamaan sebagai berikut:

$$
\begin{aligned}
& \mathbf{Y = a}+\mathbf{b}_{\mathbf{1}} \mathbf{X}_{\mathbf{1}}+\mathbf{b}_{\mathbf{2}} \mathbf{X}_{\mathbf{2}}+\mathbf{e} \\
& \text { Dimana: } \\
& \mathrm{Y} \quad=\text { Kinerja } \\
& a \quad=\text { Konstanta } \\
& b_{1}, b_{2}=\text { Koefesien regresi } \\
& X_{1}=\text { Budaya organisasi } \\
& X_{2} \quad=\text { lingkungan kerja } \\
& \mathrm{e} \quad=\text { Standart Error }
\end{aligned}
$$

\section{Uji t}

Uji - t hitung dua arah bertujuan untuk melihat secara parsial bagaimana pengaruh variabel budaya organisasi $\left(\mathrm{X}_{1}\right)$ dan lingkungan kerja $\left(\mathrm{X}_{2}\right)$ terhadap variabel kinerja (Y). Model hipotesis yang digunakan dalam uji t hitung dua arah ini adalah : Nilai $\mathrm{t}$ hitung dapat diperoleh dengan menggunakan bantuan aplikasi software SPSS 24,0 for Windows.

\section{Uji F}

Uji-F hitung dilakukan untuk melihat secara bersama-sama bagaimana pengaruh variabel budaya organisasi $\left(\mathrm{X}_{1}\right)$ dan lingkungan kerja $\left(\mathrm{X}_{2}\right)$ terhadap kinerja $(\mathrm{Y})$. Nilai F hitung dapat diperoleh dengan menggunakan bantuan aplikasi software SPSS 24.0 for Windows. Selanjutnya nilai $\mathrm{F}$ hitung akan dibandingkan dengan nilai $\mathrm{F}$ Tabel dengan kriteria kesalahan $(\alpha=5 \%)$ dan derajat kebebasan $(\mathrm{df})=(\mathrm{n}-\mathrm{k}) .(\mathrm{k}-2)$.

\section{HASIL PENELITIAN DAN PEMBAHASAN}

\section{A. Uji Validasi Data}

1. Validasi Budaya Organisasi $\left(\mathrm{X}_{\mathbf{1}}\right)$

Tabel 7

Hasil Uji Validitas Budaya Organisasi $\left(\mathbf{X}_{1}\right)$

\begin{tabular}{|c|c|c|}
\hline Butir pertanyaan & Corrected Item total Correlation & Status \\
\hline Butir 1 & 0.639 & Valid \\
\hline Butir 2 & 0.528 & Valid \\
\hline Butir 3 & 0.690 & Valid \\
\hline Butir 4 & 0.634 & Valid \\
\hline Butir 5 & 0.731 & Valid \\
\hline Butir 6 & 0.818 & Valid \\
\hline Butir 7 & 0.528 & Valid \\
\hline Butir 8 & 0.690 & Valid \\
\hline
\end{tabular}

Sumber : Hasil olah data SPSS Ver 24,0

2. Validasi Variabel Lingkungan Kerja

Tabel 8

Hasil Uji Validitas lingkungan kerja $\left(\mathrm{X}_{2}\right)$

\begin{tabular}{|c|c|c|}
\hline Butir pertanyaan & Corrected Item total Correlation & Status \\
\hline Butir 1 & 0.684 & Valid \\
\hline Butir 2 & 0.818 & Valid \\
\hline Butir 3 & 0.644 & Valid \\
\hline Butir 4 & 0.764 & Valid \\
\hline Butir 5 & 0.698 & Valid \\
\hline
\end{tabular}




\begin{tabular}{|c|c|c|}
\hline Butir 6 & 0.615 & Valid \\
\hline Butir 7 & 0.668 & Valid \\
\hline Butir 8 & 0.823 & Valid \\
\hline Butir 9 & 0.644 & Valid \\
\hline Butir 10 & 0.764 & Valid \\
\hline Butir 11 & 0.724 & Valid \\
\hline
\end{tabular}

Sumber: Hasil olah data SPSS Ver 24,0

3. Validasi Variabel Kinerja (Y)

Tabel .9

Hasil Uji Validitas Kinerja (Y)

\begin{tabular}{|c|c|c|}
\hline Butir pertanyaan & Corrected Item total Correlation & Status \\
\hline Butir 1 & 0.850 & Valid \\
\hline Butir 2 & 0.725 & Valid \\
\hline Butir 3 & 0.733 & Valid \\
\hline Butir 4 & 0.756 & Valid \\
\hline Butir 5 & 0.587 & Valid \\
\hline Butir 6 & 0.645 & Valid \\
\hline Butir 7 & 0.516 & Valid \\
\hline Butir 8 & 0.362 & Valid \\
\hline Butir 9 & 0.850 & Valid \\
\hline Butir 10 & 0.725 & Valid \\
\hline Butir 11 & 0.736 & Valid \\
\hline Butir 12 & 0.726 & Valid \\
\hline
\end{tabular}

Sumber : Hasil olah data SPSS Ver 24,0

\section{b. Uji Reliabilitas Data}

Tabel 10

Hasil Uji Reliabilitas

\begin{tabular}{|l|c|c|}
\hline \multicolumn{1}{|c|}{ Variabel } & $\begin{array}{c}\text { Alpha } \\
\text { Cronbach }(\boldsymbol{\alpha})\end{array}$ & Status \\
\hline Budaya Organisasi & 0,884 & Reliabel \\
\hline Lingkungan Kerja & 0,930 & Reliabel \\
\hline Kinerja & 0,925 & Reliabel \\
\hline
\end{tabular}

Sumber : Hasil olah data SPSS Ver 24,0 


\section{B. Analisis Deskriptif Statistik \\ 1. Koefesien Diterminasi}

Tabel 11

Koefesien Diterminasi

\begin{tabular}{|l|c|c|c|c|r|}
\hline \multicolumn{7}{|c|}{ Model Summary } \\
\hline Model & $\mathrm{R}$ & $\mathrm{R}$ Square & Adjusted R Square & $\begin{array}{c}\text { Std. Error of the } \\
\text { Estimate }\end{array}$ & Durbin-Watson \\
\hline 1 & $.780^{\mathrm{a}}$ & .608 & .637 & 7.35336 & 1.890 \\
\hline a. Predictors: (Constant), LINGKUNGAN, BUDAYA & & \\
\hline \multicolumn{2}{|l|}{ b. Dependent Variable: KINERJA }
\end{tabular}

Sumber : Hasil olah data SPSS Ver 24,0

Tabel diatas menunjukan koefisien korelasi (r) sebesar 0.780 ini berarti ada hubungan antara variabel dependen (kinerja karyawan) dengan variabel independen (budaya organisasi, dan lingkungan kerja) sebesar 0.780. Koefisien determinasi (Ajusted R Square) sebesar 0.608 ini berarti kontribusi variabel independen (budaya organisasi, motivasi, dan lingkungan kerja) mempengaruhi variabel dependen (kinerja karyawan) sebesar 60,8\% sedangkan sisanya sebesar 39,2\% dipengaruhi variabel lain diluar model.

\section{Uji Regresi Berganda}

Tabel 12

Koefesien Regresi

\begin{tabular}{|c|c|c|c|c|c|c|}
\hline \multirow{2}{*}{\multicolumn{2}{|c|}{ Model }} & \multicolumn{2}{|c|}{ Unstandardized Coefficients } & Standardized & \multirow[t]{2}{*}{$\mathrm{t}$} & \multirow[t]{2}{*}{ Sig. } \\
\hline & & $B$ & Std. Error & Beta & & \\
\hline \multirow{3}{*}{1} & (Constant) & 8,398 & 3,793 & & 5,033 & 000 \\
\hline & KOMITMEN & ,717 & ,088 & ,365 & 3,480 & ,000 \\
\hline & DISIPLIN &, 514 & 119 & ,142 & 2,962 & ,001 \\
\hline
\end{tabular}

a. Dependent Variable: $\mathrm{Y}$

Sumber : Hasil olah data SPSS V 24,0

Hasil regresinya adalah sebagai berikut :

$$
\begin{aligned}
& \mathrm{Y}=\alpha+\mathrm{b}_{1} \mathrm{X}_{1}+\mathrm{b}_{2} \mathrm{X}_{2} \\
& \mathrm{Y}=8,398+0,717 \mathrm{X}_{1}+0,514 \mathrm{X}_{2} \\
& \text { Dimana : } \\
& \mathrm{Y}=\text { Kinerja } \\
& a=\text { Konstanta } \\
& X_{1}=\text { Budaya Organisasi } \\
& X_{2}=\text { Lingkungan Kerja } \\
& b_{1}, b_{2}=\text { Koefesien regresi } \\
& \mathrm{e}=\text { Standart Error }
\end{aligned}
$$

Penjelasan secara rinci dari masing-masing variabel adalah sebagai berikut : a. Angka konstanta 8,398 dari unstandardized coefficient yang dalam penelitian ini sebesar angka ini berupa angka konstanta yang mempunyai arti : jika variabel budaya organisasi dan lingkungan kerja $0, \quad$ maka jumlah kinerja sebesar $8,398 \%$

b Angka koefisien regresi $X_{1}$ sebesar 0,717. Angka tersebut mempunyai arti bahwa setiap penambahan 1\% budaya organisasi, maka kinerja akan meningkat sebesar $17,7 \%$ 
c. Angka koefesien regresi $X_{2}$ sebesar

lingkungan kerja, maka kinerja 0,514 . Angka tersebut mempunyai akan meningkat sebesar $51,4 \%$

\section{Uji Signifikansi Secara Individu (Uji t)}

Tabel 13

Koefesien Regresi

\begin{tabular}{|c|c|c|c|c|c|c|}
\hline \multirow{2}{*}{\multicolumn{2}{|c|}{ Model }} & \multicolumn{2}{|c|}{$\begin{array}{c}\text { Unstandardized } \\
\text { Coefficients }\end{array}$} & $\begin{array}{c}\text { Standardized } \\
\text { Coefficients }\end{array}$ & \multirow[t]{2}{*}{$\mathrm{t}$} & \multirow[t]{2}{*}{ Sig. } \\
\hline & & $\mathrm{B}$ & Std. Error & Beta & & \\
\hline \multirow{3}{*}{1} & (Constant) & 8,398 & 3,793 & & 5,033 & ,000 \\
\hline & BUDAYA & ,717 & ,088 & ,365 & 3,480 & ,000 \\
\hline & $\begin{array}{l}\text { LINGKUNGA } \\
\mathrm{N}\end{array}$ & ,514 & 119 & 142 & 2,962 & 001 \\
\hline
\end{tabular}

a. Dependent Variable: $Y$

a. Pengujian variabel budaya organisasi $\left(b_{1}\right)$ dengan hipotesis :

$$
\begin{aligned}
& \mathrm{H}_{\mathrm{o}}=\text { koefiesien regresi (budaya } \\
& \mathrm{H}_{1}=\text { koefiesien regresi ( budaya }
\end{aligned}
$$

Berdasarkan hasil dari output $t_{\text {hitung }}$ diperoleh sebesar 3,480 Untuk mencari t tabel pada signifikansi 0,05 dengan derajat kebebasan $\mathrm{df}=\mathrm{n}-\mathrm{k}-1$ atau 31-2-1 $=28$ maka diperoleh nilai untuk $\mathrm{t}$ tabel sebesar 2,368. Karena $\mathrm{t}$ hitung $(3,480)>\mathrm{t}$ tabel (2,368), maka $\mathrm{H}_{0}$ diterima, $\mathrm{H}_{1}$ ditolak artinya bahwa budaya organisasi secara parsial berpengaruh terhadap kinerja.

b. Pengujian variabel lingkungan kerja $\left(b_{2}\right)$ dengan hipotesis :

$$
\begin{aligned}
& \mathrm{H}_{\mathrm{o}}=\text { koefiesien regresi (lingkungan } \\
& \text { kerja) secara parsial } \\
& \text { berpengaruh terhadap kinerja }
\end{aligned}
$$

$$
\begin{aligned}
\mathrm{H}_{1}= & \text { koefiesien regresi (lingkungan } \\
& \text { kerja) secara parsial tidak } \\
& \text { berpengaruh terhadap kinerja }
\end{aligned}
$$

Berdasarkan hasil dari output $t_{\text {hitung }}$ diperoleh sebesar 2,926 Untuk mencari $\mathrm{t}$ tabel pada signifikansi 0,05 dengan derajat kebebasan $\mathrm{df}=\mathrm{n}-\mathrm{k}-1$ atau $31-2-1=28$ maka diperoleh nilai untuk $\mathrm{t}$ tabel sebesar 2,368. Karena $t_{\text {hitung }}(2,926)>t_{\text {tabel }}(2,368)$, maka $\mathrm{H}_{\mathrm{o}}$ diterima, $\mathrm{H}_{1}$, ditolak artinya bahwa lingkungan kerja secara parsial berpengaruh terhadap kinerja

c. Uji Signifikansi Secara Bersama-sama ( uji f)

Uji-F atau uji koefesien regresi secara bersama-sama digunakan untuk mengetahui apakah secara bersama-sama variabel independen berpengaruh signifikan terhadap variabel dependen. Dalam hal ini untuk mengetahui apakah variabel budaya organisasi dan lingkungan kerja berpengaruh secara signifikan atau tidak terhadap kinerja. Pengujian menggunakan tingkat signifikansi 0,05. 
Tabel 14

ANOVA

ANOVA $^{a}$

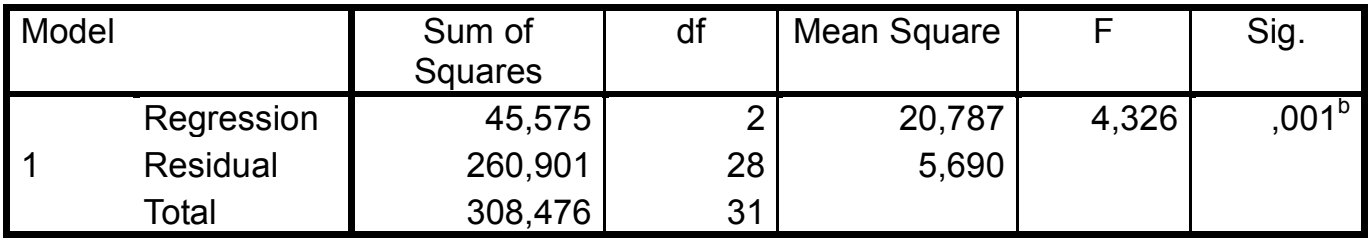

a. Dependent Variable: KINERJA

b. Predictors: (Constant), BUDAYA, LINGKUNGAN

Sumber: Hasil olah data SPSS V 24,0

$\mathrm{H}_{0}: \mathrm{b}_{1}, \mathrm{~b}_{2}=0$, artinya secara bersama-sama terdapat pengaruh yang positif dan signifikan dari variabel bebas $\left(\mathrm{X}_{1}, \mathrm{X}_{2}\right)$ yaitu berupa budaya organisasi dan lingkungan kerja terhadap kinerja karyawan sebagai variabel terikat $(\mathrm{Y})$.

$\mathrm{H}_{1}: \mathrm{b}_{1}, \mathrm{~b}_{2} \neq 0$, artinya secara bersama-sama tidak terdapat pengaruh yang positif dan signifikan dari variabel bebas $\left(\mathrm{X}_{1}, \mathrm{X}_{2}\right)$ yaitu berupa budaya organisasi dan lingkungan kerja terhadap kinerja karyawan sebagai variabel terikat (Y).

Berdasarkan hasil dari output $\mathrm{F}$ hitung diperoleh nilai sebesar 4,326 Untuk mencari $F$ tabel pada signifikansi 0,05 dengan derajat kebebasan $\mathrm{df}=\mathrm{n}-\mathrm{k}-1$ atau 31-2-1 = 28 maka diperoleh nilai untuk $F$ tabel sebesar 3,340. Karena $F$ hitung $(4,326)>$ $F$ tabel $(3,340)$, maka $H_{\circ}$ diterima, $H_{1}$ ditolak, artinya bahwa budaya organisasi dan lingkungan kerja secara bersama-sama (simultan) berpengaruh terhadap kinerja.

\section{PENUTUP}

\subsection{Simpulan}

Berdasarkan hasil penelitain dan pembahasan diperoleh simpulan dan saran sebagai berikut:
1. Ada pengaruh budaya organisasi terhadap kinerja yang artinya budaya organisasi pada CV. Revari Putra Pratama, sehingga mendukung hipotesis 1 dimana budaya organisasi berpengaruh terhadap kinerja karyawa hal ini berdasarkan hasil uji $\mathrm{t}$ dimana nilai $\mathrm{f}$ hitung sebesar $(3,480)>$ nilai $t$ tabel sebesar $(2,368)$.

2. Ada pengaruh lingkungan kerja terhadap kinerja karyawan pada CV. Revari Putra Pratama, sehingga mendukung hipotesis 2 dimana lingkungan kerja berpengaruh terhadap kinerja karyawa hal ini berdasarkan hasil uji t dimana nilai $f$ hitung sebesar $(3,480)>$ nilai $t$ tabel sebesar $(2,926)$.

3. Ada pengaruh budaya organisasi dan lingkungan kerja secara bersama-sama terhadap kinerja karyawan $\mathrm{CV}$. Revari Putra Pratama. Besarnya pengaruh budaya organisasi dan lingkungan organisasi terhadap kinerja karyawan

\subsection{Saran}

Beberapa saran yang dapat peneliti berikan terkait dengan hasil penelitian ini antara lain :

1. Berdasarkan hasil penelitian yang dilakukan peneliti bahwa budaya organisasi yang diterapkan dlama perusahaan perlu ditingkatkan untuk menyatukan hubungan social kerja 
sama anggota karyawan, karyawan dengan atasan dan untuk mengontrok Tindakan sertia perilaku anggota karyawan.

2. Hendaknya lingkungan kerja yang tersedia di perusahaan CV. Revari Putra Pratama Palembang, agar setiap karyawan semakin nyaman, aman dan tenang pada saat melakukan dan menyelesaikan pekerjaan di perusahaan. Lingkungan kerja ditingkatkan yaitu lingkungan kerja fisik maupun non fisik seperti menjaga hubungan yang baik antara sesama karyawan maupun atasan.

\section{DAFTAR PUSTAKA}

Edy Sutrisno, Manajemen Sumber Daya Manusia. Edisi Pertama, Cetakan Pertama. Penerbit Kencana, Jakarta, 2012

Fred Luthans, Perilaku Organisasi, Diterjemahkan oleh Vivin Andika, Yuwono, Edisi ke kelima, Penerbit Andi, Yogyakarta, 2015

Guritno, Bambang dan Waridin, Pengaruh Persepsi Karyawan Mengenai Perilaku Kepemimpinan,Kepuasan Kerja dan Motivasi Terhadap Kinerja. JRBI, Vol.1 No. 1, pp.63-74,

Hasibuan, SP. Malayu, Manajemen Sumber Daya Manusia , Bumi Aksara, Jakarta, 2015

Ismail Nawawi, Budaya Organisasi Kepemimpinan dan Kinerja, Kencana, Jakarta, 2016

Hari Sulaksono,Budaya Organisasi Dan Kinerja, Pendidikan Deepublish, Jakarta, 2013

Robert Kreitner. Perilaku Organisasi. Edisi 9. Buku 1. Salemba Empat. Jakarta:, 2014
Pabundu Tika, Budaya Organisasi Dan Peningkatan Kinerja Perusahaan, Bumi Aksara, 2016

Rachmawati,E.Paradigma Baru Manajemen Sumber Daya Manusia Sebagai Basis Meraih Keunggulan Kompetitif Ekoni,s, Yogyakarta, 2014

Sugiyono, Metode Penelitian Bisnis, Alfabeta, Bandung, 2015

Sedarmayanti, Sumber Daya Manusia Dan Produktivitas Kerja, Mandar Maju, Bandung, 2015

Sarwoto, Efektivitas Organisasi, Erlangga, Jakarta. 2016

Stephen P. Robbins, Timothy A. Judge, Perilaku Organisasi (Edisi 16), Salemba Empat, Jakarta, 2015

Sondang P. Siagian, Manajemen Sumber Daya Manusia, Bumi Aksara, Jakarta, 2014

Syafrizal Helmi Situmorang, Filasafat Ilmu dan Metode Riset, Usu Press, Medan, 2015

Veithzal Rivai,Manajemen Sumber Daya Manusia Untuk Perusahaan, Edisi Kedua, Raja Grafindo, Jakarta, 2015

Wilson Bangun, Manajemen Sumber Daya Manusia, Erlagga, Jakarta, 2015 